\title{
Role of Supportive Leadership as a Moderator between Job Stress and Job Performance
}

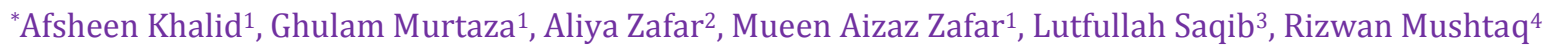 \\ ${ }^{1}$ Air University Islamabad, Pakistan \\ ${ }^{2}$ COMSATS Institute of Information Technology (CIIT), Pakistan \\ ${ }^{3}$ Riphah International University, Islamabad, Pakistan \\ 4International Islamic University, Islamabad, Pakistan \\ *afsheenlibra@gmail.com
}

\begin{abstract}
Stress is a major problem faced by employees in the working environment that affects performance. This problem can be resolved if employees receive support from their leaders. This study was conducted to examine the moderating effect of supportive leadership on the relationship between job stress and job performance. Supportive leadership is an important factor enhancing employee performance in organizations. In this research, 200 employees were considered from 4 educational institutions. Data was collected using a well-developed questionnaire. The empirical results reveal that supportive leadership has a negative effect on job stress and directly impacts job performance. The study also revealed that Supportive Leadership moderates the relationship between these constructs. The paper concludes with recommendations for further research.
\end{abstract}

Keywords: Supportive leadership, job stress, job performance, educational institutes

\section{Introduction}

The number of educational institutes in Pakistan has increased enormously during the past few years, thereby increasing a strong competition among them. The management and employees put their best effort to attain an eminent position among the competitors. Excessive load of work on teachers and administrative staff increase their problems thus leading to job stress, which affects employee performance. According to Eyal \& Roth (2011) there are many exogenous factors in the educational setting that create hindrances for the educational staff thereby affecting their performance, motivation, comfort level, and increase the stress levels (Retelsdorf et al, 2009). Geijsel et al., (2003) deduced that Individualized consideration (supportive leadership behavior) which includes the leader's support of subordinates' professional and personal development helps to promote teachers' sense of competence, self-efficacy, and motivation. Graen \& Cashmen (1975) found that supportive leadership enhances the relationship between superiors and employees and lessens the stress levels of employees. When people are under stress, they lose their ability to use their dayto-day intelligence and rely on their experiences. At that point, intellect is negatively associated with their performance (Fiedler \& Garcia, 1987). Cobb (1976) suggested that social support from colleagues and supervisors decreases the level of stress among employees thus enabling them to cope with it. In this regard, the supportive leader plays an important role in motivating employees by providing them with a friendly and pleasant environment, thus decreasing their job stress and helping them to work in a better way. Leadership has been the topic of discussion for many years and many theories were proposed in this regard. The trait theory emerged with the assumption that people inherit some qualities and traits of leadership. In other words, we may say that this ability is inborn. The Behavioral approach asserted that leaders are made, not born and people can learn to become leaders. The Contingency theory contended that it depends upon the situation that which leadership style is effective (Bryman, 1993). Later two more styles of leadership were presented by Burns called transactional and transformational leadership (Deluga, 1995). Leadership was presented into four frames by Bolman \& Deal (1994) as structural, human resource, political and symbolic frameworks. Then the House's (1971) path goal theory was introduced explaining four leadership styles for different attitudes in different situations. These are: directive, supportive, participative and achievement oriented. 
This theory became the main theme of supportive leadership. Supportive leadership is a behavior that addresses the requirements and preferences of the employees and shows concern for their wellbeing and fosters a pleasant and friendly, psychological organizational setting (House \& Mitchell, 1974). Effective leaders balance between initiation structure and consideration (supportive leadership style) to reduce job stress in the organization to achieve organizational goals (Jam et al., 2010). The moderating impact of supportive leadership on the stress-strain relationship has been examined in past researches but few studies have been conducted to investigate the role of supportive leadership as a moderator on the relationship between job stress and job performance. La Rocco and Jones (1978) examined the impact of leaders and peer support as a moderating variable between job stress and strain on a sample of 3, 725 US Navy employees. They found that the social climate and interpersonal relationships had a moderating impact on participants' reaction to the job stressors (Kahn et al., 1964). Wallace et al. (2009) suggested that influence of leadership styles and their impact on important work variables must be studied. Therefore, this study is designed to examine supportive leadership as a moderator between job stress and job performance. This study examined ways of reducing the stress levels of employees working in the educational sectors through supportive leadership thereby enhancing their performance. Educational institutions play a very important role in a nation's prosperity. An institute's performance increases its reputation. According to this study, if institutes in Pakistan want to compete with institutes at international levels they should focus on increasing their performance. The present study aimed to investigate the relationship supportive leadership and job stress/ stress in developing countries like Pakistan. The study also focused on providing recommendations for academicians and management by contributing to an understanding of the moderating impact of supportive leadership on job stress and job performance. It will also aid in understanding how to address performance issues and stress levels of diverse individuals. In addition, it will provide guidance in formulating strategies and in decision-making processes and present insights on the important role of supportive leadership in moderating the relationship between stress and performance.

\section{Literature Review}

Leadership is neither a position, designation nor the action of an exclusive "leader." Instead, it is an interactive procedure in which leaders and followers engage in mutual goals (Wren, 1995). There is a strong need for a leader, when there is a situation where someone is required to bring a change and provide guidance (English, 1992). When an organization is going to incorporate change, at that time people look for a leader who can provide guidance and become a source of inspiration for others (Bolman \& Deal, 1994). Leader's support plays a key role in alleviating the stress level of employees and encourages them to show better performance. When the social support increases, it moderates the negative affect of stress on the employees. The subject of stress and its impact on job outcome is being given importance in the research area.

Job Stress: Job stress, and its relationship to both individual and organizational outcomes, has become an important area of study in recent years. Job stress occurs when demands surpass abilities, whereas job related strains are reactions or outcomes resulting from the experience of stress (Westman, 2005). A feeling of personal dysfunction as a result of events happening in the organization and the psychological and physiological responses because of pressures in the work setting is considered job stress (Montgomery et al., 1996). Researchers have studied stress in three perspectives: individual differences, environmental factors, and the interplay of both (Parker \& Decottis, 1983). Stress can influence a variety of variables including job performance (Welford, 1973), organizational effectiveness (Borucki, 1987), personal relationships, and health (Bosma, et al., 1998). In an organizational setting quality of supervision, job content, time pressures, and anxiety are considered major job stressors and affect the performance of employees in one way or the other. The present study measures job stress, time stress and anxiety as identified by Parker and Decottis (1983). However, many job stressors have been identified in literature but limited research has been done on the above-mentioned variables as they play an important role in reducing stress. Many researchers including Schuler et al. (1977) and La Rocco and Jones (1978) found that little attention had given to identifying those elements, which can significantly lower stress levels at the workplace. Bowen and Schuster (1986) and Smith et al. (1995) discussed the impact of stress among faculty members at university level and identified it as a major problem for them. Stress affects the performance of employees making it difficult for them to achieve the desired targets. 
Job Performance: Performance is a measure of a person's ability to execute a specific task (Goodhue \& Thompson, 1995). Job performance is the extent to which employees make efforts to achieve organizational goals (Greguras et al., 1996). It is how an employee strives to attain the goals of the organization and tries to achieve the standard set up by the organization (Bohlander et al. 2001; Eysenck, 1998). McCloy et al. (1994) viewed performance as multidimensional based on the actions or behaviors that relate to the organizational goals. Task performance and contextual performance are studied as the two dimensions of job performance by Motowidlo \& Van Scotter (1994). Behavior that is associated with keeping and servicing an organization's technical core is termed as task performance and contextual performance and viewed as the function of one's interpersonal skills. It supports the social environment and is linked with helping and cooperative elements of enviable behavior within the organization.

Job Stress and Job Performance: Individuals who are prone to job stress show lower levels of performance and are mostly unable to deliver their best. When people working in organizations face higher levels of stress, their performance is decreased (Elovainio et al., 2002; Jamal, 1984). Research suggests that the relationship between job stress and job performance exists in different sectors like banking (Kakkos \& Trivellas, 2011), medical (Kazmi et al., 2008), and multinational companies. Findings were quite similar across studies conducted to assess this relationship and revealed that a negative link was found between job stress and performance. A study conducted on a sample of 143 employees at universities, banks and multinational companies showed that those employees who were experiencing more stress at their jobs were unable to perform to expectations (Dar et al., 2011). Employees serving in the medical field and finance sector confirmed these findings as their performance was also negatively affected by stress (Imtiaz \& Ahmed, 2009, $\mathrm{Wu}, 2011$ ). Lower levels of performance were also witnessed among the 144 banking professionals due to job stress (Bashir \& Ramay, 2010). These findings suggest that maintain a prominent position at the workplace it is very important to deliver outstanding performance. However, when employees face stress at their jobs they cannot focus on their work and face difficulty in performing tasks. Therefore, the following hypotheses guided this study:

Hypothesis- 1: Job stress is negatively related to job performance

Supportive Leadership: Path goal theory formulated by House (1971) states that the leader's job is to assist his followers in accomplishing their goals, specifying direction, providing support and to ensure that their goals are well matched with organization goals. Four kinds of behaviors: directed, participative, achievement oriented and supportive leadership was identified by House \& Mitchell (1974) Supportive leadership is the behavior, which focuses on the wellbeing of employees and has a deep concern for the needs, preferences and satisfaction of employees (House, 1971). Leaders who are aware of their duties and responsibilities and able to encourage their subordinates are considered to be supportive leaders. Supportive leaders create conducive working environment to foster respect, trust, cooperation, and emotional support (Daft, 2005; Gibson et al., 2000). A workplace enriched with supportive leaders brings successful results that are beneficial for the wellbeing of both employees and the organization. Supportive leadership is categorized into two dimension i.e. instrumental (making one's life easier) and emotional (ease of talking with) elements (La Rocco \& Jones, 1978).

Supportive Leadership and Job Performance: Oluseyi and Ayo (2009) discussed leadership in terms of the leader's role and ability to get the work done by subordinates in an effective manner. Leadership is an essential attribute for better organizational performance. Support from the leader motivates employees; i increase their performance, and improve their concentration level. According to Avolio and Bass (1995), a supportive leader has high concern for individual consideration. Supportive leadership is the sub-dimension of transformational leadership is featuring individualized consideration (Rafferty \& Griffin, 2006). Such leaders support every subordinate to strive for higher performance and assist him or her to solve the work related issues. In these way leaders, help subordinates to avoid stress. It is a role of a leader to understand the needs of employees and address them properly. Researchers (Dumdum et al., 2002: Judge et al., 2004) confirmed the direct effects of consideration (supportive leadership) on performance. If the leader is supportive and considerate and stimulates understanding and motivation then it will be helpful in getting tasks accomplished by employees efficiently and effectively. A number of studies have observed a significant, positive relationship between supervisor consideration and subordinate performance (Farris \& Lim, 1969; Greene, 1975; Lowin \& Craig, 1968). This guided the second hypothesis for this study: 
Hypothesis 2 a: The supportive leadership is positively related to job performance

Supportive Leadership and Job Stress: There are many factors in our surroundings that increase stress level at the workplace i.e. extended work hours and lack of support in the organizational setting (Davey et al, 2001). Some other factors like role conflict and role ambiguity have been quoted frequently as sources of jobrelated stress and have been found to be associated with various negative attitudinal behavioral outcomes (Brief \& Aldag, 1976; Szilagyi et al., 1976). A major factor that causes the stress is lack of supportive leadership (Leka et al., 2004). House (1996) found that when the employees are facing psychological and psychical stress at the work place there is a need for supportive leadership. At that point, of time supportive leadership gives self-confidence to the subordinates and helps them to lower their stress, anxiety and recompenses for the unpleasant effects. In the educational sector, it has been witnessed that faculty members who were facing higher levels of stress had more propensities to psychological distress (Chan, 1998). There is a need to provide support, which helps to alleviate stress levels. Supportive leaders ensure the involvement of faculty members in decision-making processes and provide them growth opportunities. They focus on the concerns that affect their requirements (Sass et al., 2011). The educational sector of Pakistan should provide opportunities for people to develop supportive leadership skills because this will help to reduce the stress level among faculty working in educational institutions. Therefore the third hypothesis was:

Hypothesis $\mathbf{2}$ b: The supportive leadership is negatively related to job stress

Supportive leadership as a Moderator: Supportive leadership (individualized consideration) improves the job performance without raising the levels of work stress (Rowold \& Schlotz, 2009). When employees find a supportive attitude from their leaders they work with more devotion and deal with job stress in a better way. They do not let stress affect or disrupt their performance. It has been witnessed that along with supportive leadership, the support from colleagues also plays a convincing role to handle stress and perform well. Beehr and Love (1980) confirmed the findings by showing the results that the employees who gain support from both supervisors and colleagues can cope with higher levels of job stress and do not feel more stressed out as compared to those who lack this support. When employees receive support from tleaders and have low job stress they are better able to achieve their goals (La Rocco \& Jones, 1978). Those employees who work with supportive supervisors are more satisfied and have low stress levels. Similar results were shown in a study conducted by Ahmad and Halim (1982) where supportive leadership was investigated as a moderator. Findings are in alignment with the path goal theory of leadership discussed by House (1971) and House and Mitchell (1974), which focuses on the requirement of supportive leadership for employees facing job stress. It says supportive leaders show concern for the employees, work for their welfare and contribute to a friendly environment. It leads to a positive impact on the performance of employees and makes the job interesting for them. This approach of leadership is best in the situations where employees are under stressful conditions. Imtiaz and Ahmed (2009) also found that the employees who lacked sufficient support from their leaders did not show better performance as compared to those who experienced supportive leadership. It is obvious from tpast researched that employees who are more liable to stress have low urge to show a better performance (Rose, 2003) and at that point management support can play a vital role in reducing the level of stress (Stamper \& Johlke, 2003). Management support actually functions as a buffer, which acts in a positive manner to deduce the stress and increases the level of performance. Therefore, the next hypothesis stated:

Hypothesis 3: Supportive leadership moderates relationship between job stress and job performance Consistent with the structure used above this section should discuss the $3^{\text {rd }}$ hypothesis with reference to the literature before moing to the research framework.

\section{Research Framework}

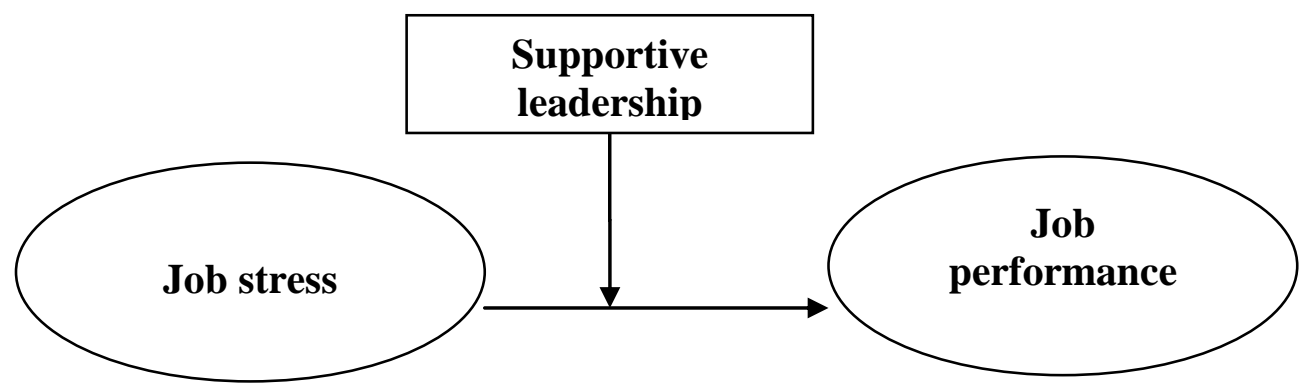




\section{Methodology}

Sample: Educational institutions are the backbone for any nation as they play a vital role in the progress of that nation. It is important that educational institutions should provide quality education which is only possible when people working in the in this sector will show outstanding performance by adopting appropriate ways of coping with stress level which is possible through supportive leadership. The present research was conducted on four educational institutions of Islamabad and Rawalpindi (Pakistan). Data were collected from 200 respondents, which comprised section heads, coordinators, teachers, and other admin staff serving in those institutions. The sampling technique used was Convenience Sampling that is a type of non-probability sampling. Out of 200 distributed questionnaires, 169 were received back. Since 31 were, incomplete only 169 were included in the study/analysis. Therefore, the response rate was 84.5 percent.

Measures: Supportive leadership was measured using The Leader Behavior Description Questionnaire developed by Hemphill and Coon (1957) and translated by Rahima Bt. Ahamd (1981) and five items from multifactor's leadership questionnaires (MLQ) designed by Bass and Avolio (1997) were also added. The Cronbach alpha reliability of the scale was 0.92 in this study. Example for these items include: He extended a personal aid to the staff; he often tried new ideas with all staff. A five-point Likert scale was employed ranging from 1 (strongly disagree) to 5 (strongly agree). Job stress scale was adapted from the Parker and Decotiis (1983) 13-item scale to measure job stress and the cronbach alpha reliability of the scale was 0.923 in this study. Example of the items include: I have felt fidgety or nervous as a result of my job, working here makes it hard to spend enough time with my family. A five-point Likert scale was employed ranging from 1 (strongly disagree) to 5 (strongly agree). Job performance was measured by a scale used by Reio (1997) and the cronbach alpha reliability of the scale was 0.93 in this study (was this statistically significant? Please mention). The items included: How would you rate your overall job performance? In comparison with your peers, how would you rate your overall job performance? A five-point? Scale was employed ranging from 1 (poor) to 5 (very good).

\section{Results}

Table 1 reveals the demographic profile of the present study.

Table 1: Descriptive Statistics

\begin{tabular}{llcccc}
\hline Items & $\mathbf{N}$ & Minimum & Maximum & Mean & Standard Deviation \\
\hline Gender & 169 & 01 & 02 & 1.5089 & .50141 \\
Age & 169 & 25 & 59 & 1.8994 & .61378 \\
Marital Status & 169 & 01 & 02 & 1.6450 & .47994 \\
Education & 169 & 10 & 16 & 2.6568 & .47619 \\
Experience & 169 & 05 & 30 & 1.6331 & .65126 \\
Job Category & 169 & 01 & 03 & 1.6213 & .72277 \\
\hline
\end{tabular}

Table 1 shows that a total of 169 respondents participated in this survey, mean and standard deviation were calculated, correlation (Table 2) and regression analysis (Table 3) were used to find/analyze the association and impact of independent variables on dependent variable.

Table 2: Correlation Result

\begin{tabular}{|c|c|c|c|c|}
\hline Item & JS & SP & JP & JSXJP \\
\hline JS & 1 & & & \\
\hline SP & $\begin{array}{c}-.341^{* *} \\
.000\end{array}$ & 1 & & \\
\hline $\mathrm{JP}$ & $-.235^{* *}$ & .285 & 1 & \\
\hline JSXSP & $\begin{array}{c}.002 \\
.892^{* *} \\
.000\end{array}$ & $\begin{array}{c}.001 \\
.110 \\
.002\end{array}$ & $\begin{array}{l}.391^{* *} \\
.000\end{array}$ & 1 \\
\hline
\end{tabular}


Correlation was used to study the degree of association between different variables under consideration of the present study i.e. job stress, job performance and supportive leadership. The above table shows that job stress and job performance are negatively correlated. Supportive leadership is found to be positively correlated to job performance and negatively to the job stress. It is also evident from the results that supportive leadership has a moderation effect on the variables.

Table 3: Regression Analysis

\begin{tabular}{lclll}
\hline & Model & Un-standardized Coefficients & t- value & Sig \\
& B & Standard Error & \\
\hline JS & -.196 & .040 & -4.902 & .000 \\
SP & -.321 & .062 & -5.137 & .000 \\
JSXSP & .218 & .009 & 25.552 & .000
\end{tabular}

$\mathrm{R}^{2}=.185$, Adj. $\mathrm{R}^{2}=.175$, F-Value $=18.805, \mathrm{p}$ value $=0.000$

$\mathrm{R}^{2}=.240$, Adj. $\mathrm{R}^{2}=.226, \mathrm{R}^{2}$ Change $=.055, \mathrm{~F}-$ Value $=11.990, \mathrm{p}$ value $=0.001$

Regression analysis was used to assess the impact of job stress and supportive leadership and to find the impact of supportive leadership as a moderator. The standardized coefficient of regression for job stress (.365) shows it is negatively and significantly related with dependent variable. Supportive leadership (-.383) is also found to have negative correlation with the variable and its value is significant. The results show that supportive leadership is a moderator for the relationship between job stress and performance. It also demonstrates that the strength of such relationship has been affected positively. Coefficient $\left(R^{2}=.185\right)$ for model 1 shows that $18.5 \%$ variations is explained by the predictors and the F-value shows that model is significant $(\mathrm{p}<0.05)$. The $\mathrm{R}^{2}=.240$ and the $\mathrm{R}^{2}$ change $=.055$ shows that supportive leadership is moderating the relation between job stress and job performance as the variation explained by the model after incorporating the moderating variable is $24 \%$ with the $\mathrm{R}^{2}$ change value as $5.5 \%$ and the model is significant.

Discussion: Many researchers have highlighted that stress affects the performance of employees. The results of the present study also confirmed the findings discussed in prior research and revealed the inverse relationship between job stress and job performance. The results of this study are consistent with the findings of Kazmi et al. (2008), Kakkos \& Trivellas (2011) \& Wu (2011) which also showed a negative relationship between job stress and job performance. The findings of the study are also consistent with the studies conducted by different researchers including Dar et al. (2011), Dumdum et al. (2002), Stamper \& Johlke, (2003), Rowold \& Schlotz (2009) and Ahmed \& Halim (1982). When employees serving in any organization receive support from their leaders, the level of stress decreases and job performance is improved. Employees always want to have a leader who cares for them, understands their problems and helps to solve problems. In this regard, the present study assessed the impact of supportive leadership on the relationship between job stress and job performance of the employees working in educational institutions. Employee's performance declines when thy meet high level of stress, which can be improved through a supportive leader who keeps employees, motivated even at the unfavorable situations. It means that supportive leadership plays a moderating role in the relationship between stress and performance.

\section{Conclusion and Recommendations}

The purpose of this research paper was to study the impact of supportive leadership as a moderator between job stress and job performance. The results showed significant relationships between three variables: supportive leadership, job stress and job performance. Findings suggested that employees working in the educational institutions of Rawalpindi and Islamabad under supportive leadership have less job stress and perform better on the job. Although the present study witnessed the impact of stress on job performance, the significant role of supportive leadership in coping with stress and increasing job performance was also highlighted (Shikieri, \& Musa, 2012). Findings of the study also confirmed that supportive leadership plays an important role as a moderator between the stress and performance levels of employees, faculty, and administration, and at educational institutions of Rawalpindi and Islamabad. Job stress creates hindrances in achievement of goals and also reduces the performance level of employees. Employees working at the 
organization have a responsibility on their shoulders that they have to work for the betterment of the organization and help the organization to hold an eminent position in the market. In the light of path goal theory by House and Mitchell (1974) it is quiet clear that supportive leadership plays an important role in reducing stress and increasing performance and its importance cannot be over emphasized. Leaders should be fully aware that his support is important for those who are serving in the organization and it is only with the support of the leader that employees can cope with stress and perform better. Recommendations for the management at educational institutions may emphasis the performance and stress issues faced by employees. Policies are required that enhance the performance and reduce stress. Along with that, the working environment should be supportive for the employees because employees can perform up to the mark if the leader is supportive and considerate.

Limitations: Finally, there were some limitations to the study, which should be kept in consideration. Firstly, the sample size was limited and numbers of educational institutes were few. The study should also be carried out in other sectors of Pakistan including the banking sector; medical sector, telecom sector etc. Future study should involve more variables for more conclusive results.

\section{References}

Ahmed, A. \& Halim, A. (1982). Social support and managerial affective responses to job stress. Journal of Occupational Behavior, 3(4), 281-295.

Avolio, B. J. \& Bass, B. M. (1995). Individual consideration viewed at multiple levels of analysis: A multi-level framework for examining the influence of transformational leadership. Leadership Quarterly, 6, 199218.

Bashir, U. \& Ramay, M. I. (2010). Impact of stress on employees' job performance a study on banking sector of Pakistan. International Journal of Marketing Studies, 2(1), 122-126.

Bass B. M. \& Avolio, B. J. (1997). Full Range of Leadership Development: Manual for the Multi-factor Leadership Questionnaire. California: Mind Garden Inc.

Beehr, T. A. \& Love, K. G. (1980). Social stressors on the job: A review and recommended new directions. Paper presented at the annual meeting of the National Academy of Management, Detroit.

Bohlander, G., Snell, S. \& Sherman, A. (2001). Managing human resources. USA: South-Western College Publishing.

Bolman, L. G. \& Deal, T. E. (1994). Looking for leadership: Another search party's report. Educational Administration Quarterly, 30(1), 77.

Borucki, Z. (1987). Perceived organizational stress, emotions, and negative consequences of stress: Global self-esteem and sense of interpersonal competence as moderator variables. Polish Psychological Bulletin, 18(3), 139-148.

Bosma, H., Peter, R., Siegrist, J. \& Marmot, M. (1998). Two alternative job stress models and the risk of coronary heart disease. American Journal of Public Health, 88(1), 68-74.

Bowen, H. R. \& Schuster, J. H. (1986). American professors: A national resource imperiled. New York: Oxford University Press.

Brief, A. P. \& Aldag, R. J. (1976). Correlates of role indices. Journal of Applied Psychology, 61, 468-472.

Bryman, A. (1993). Charisma and leadership in organizations. Some neglected issues. Leadership Quarterly, 4 (3/4), 289-304

Chan, D. W. (1998). Stress, coping strategies, and psychological distress among secondary school teachers in Hong Kong. American Educational Research Journal, 35(1), 145-63.

Cobb, S. (1976). Social support as a moderator of life. Stress, 38, 300-314.

Daft, R. L. (2005). The leadership experience. (3 ${ }^{\text {rd }}$ Ed). Toronto: Thompson South Western.

Dar, L., Akmal, A., Naseem, M. A. \& Khan, K. D. (2011). Impact of stress on employee's job performance in business sector of Pakistan. Global Journal of Management and Business Research, 11(6).

Davey, J., Obst, P. \& Sheehan, M. (2001). Demographic and workplace characteristics, which add to the prediction of stress and job satisfaction within the police workforce. Journal of Police and Criminal Psychology, 16(1), 29-39.

Deluga, R. J. (1995). Relationship of transformational and transactional leadership with employee influencing strategies. Leaders and the leadership process: Readings, self-assessments and applications. IL: Austin Press. 
Dumdum, U. R., Lowe, K. B. \& Avolio, B. J. (2002).A meta-analysis of transformational and transactional leadership correlates of effectiveness and satisfaction: An update and extension. In B. J. Avolio \& F.J.Yammarino (eds.), Transformational and Charismatic leadership: The road ahead, 2, 35-66.0xford, U.K: Elsevier Sciences.

Elovainio, M., Kivimaki, M. \& Vahtera, J. (2002). Organizational justice: Evidence of a new psychosocial predictor of health. American Journal of Public Health, 92(1), 105-108.

English, F. W. (1992). Educational administration: The human science. New York: Harper-Collins.

Eyal, 0. \& Roth, G. (2011). Principals' leadership and teachers' motivation: Self-determination theory analysis. Journal of Educational Administration, 49(3), 256-275.

Eysenck, M. (1998). Psychology: An integrated approach. Harlow: Addison Wesley Longman Ltd.

Farris, G. C. \& Lim, F. G. Jr. (1969). Effects of performance on leadership influence, satisfaction, and subsequent performance. Journal of Applied Psychology, 53, 490-7.

Fiedler, F. E. \& Garcia, J. E. (1987). New approaches to effective leadership: Cognitive resources and organizational performance. New York: Wiley.

Geijsel, F., Sleegers, P., Leithwood, K. \& Jantzi, D. (2003). Transformational leadership effects on teachers' commitment and effort toward school reform. Journal of Educational Administration, 41(3), 228-56.

Gibson, J. L., Ivancevich, J. M. \& Donnelly, J. H. (2000). Organizations: Behavior, structure, processes. 10th ed. Boston: McGraw-Hill.

Goodhue, D. L. \& Thompson, R. L. (1995). Task-technology fit and individual performance. MIS Quarterly, 19 (3), 213-236.

Graen, G. \& Cashman, J. F. (1975). A role-making model of leadership in formal organizations: A developmental approach. IN J.G. Hunt \& L.L. Larsen (Eds.) Leadership Frontiers, 143-165, Kent, OH: Kent State University Press.

Greene, C. N. (1975). The reciprocal nature of influence between leader and subordinate. Journal of Applied Psychology, 60, 187-193.

Greguras, G. J., Ployhart, R. E. \& Balzer, W. K. (1996). Performance appraisal training program for wood county council on alcohol and drug abuse. Bowling Green, OH: Bowling Green State University, Institute for Psychological Research and Application.

Hemphill, J. K. \& Coons, A. E. (1957). Development of the leader behavior description questionnaire. In R. Stogdill and A. Coons, (Eds.,), Leader Behavior: Its Description and Measurement. Columbus, Ohio: Bureau of Business Research.

House, R. J. (1971). A path-goal theory of leader effectiveness. Administrative Science Quarterly, 16, 321-338.

House, R. J. \& Mitchell, T. R. (1974). Path-goal theory of leadership. Journal of Contemporary Business, 3, 81-97.

House, R. J. (1996). Path goal theory of leadership: lesson legacy and a reformulated theory. Leadership quarterly, 7(3), 324-352.

Imtiaz, S. \& Ahmed, M. S. (2009). The impact of stress on employee productivity, performance and turn over: An important managerial issue. International Review of Business Research Paper, 5(4), 468-477.

Jam, F. A., Akhtar, S., Inam, H., Rehman, M. A. \& Hijazi, S. T. (2010). Impact of leader behavior on employee job stress: Evidence form Pakistan. European Journal of Economics, 21, 172-179.

Jamal, M. (1984). Job stress and job performance controversy: An empirical assessment. Organizational Behavior and Human Performance, 33, 1-21.

Judge, T. A., Piccolo, R. F. \& Ilies, R. (2004). The forgotten ones? The validity of consideration and initiating structure in leadership research. Journal of Applied Psychology, 89, 36-51.

Kahn, R., Wolfe, D., Quinn, R., Snoek, J. \& Rosenthal, R. (1964). Organizational stress: Studies in role conflict and ambiguity. New York: Wiley.

Kakkos, N. \& Trivellas, P. (2011). Investigating the link between motivation, work stress and job performance. Evidence from the banking industry. 8th International Conference on Enterprise Systems, Accounting and Logistics, 408-428.

Kazmi, R., Amjad, S. \& Khan, D. (2008). Occupational stress and its effect on job performance. A case study of medical house officers of Abbotabad. JAMC, 20(3), 135-139.

LaRocco, J. M. \& Jones, A. P. (1978). Co-worker and leader support as moderators of stress-strain relationships in work situations. Journal of Applied Psychology, 63(5), 629-634.

Leka, S., Griffiths, A. \& Cox, T. (2004). Work organization and stress, systematic problem approaches for employers, managers and trade union representatives. Geneva: WHO. 
Lowin, A. \& Craig, J. R. (1968). The influence of level of performance on managerial style: An experimental object-lesson in the ambiguity of correlational data. Organizational behavior and Human Performance, 3, 440-458.

McCloy, R. A., Campbell, J. P. \& Cudek, R. (1994). A confirmatory test of a model of performance determinants. Journal of Applied Psychology, 79(4), 493-504.

Montgomery, D. C., Blodgett, J. G. \& Barnes, J. H. (1996). A model of financial securities sales persons job stress. The Journal of Services Marketing, 10(3), 21-34.

Motowidlo, S. J. \& Van Scotter, J. R. (1994). Evidence that task performance should be distinguished from contextual performance. Journal of Applied Psychology, 79(4), 475-480.

Oluseyi, S. A. \& Ayo, H. T. (2009). Influence of work motivation, leadership effectiveness and time management on employees' performance in some selected industries in Ibadan, Oyo State, Nigeria. European Journal of Economics, Finance and Administrative Sciences, (16).

Parker, D. F. \& Decotiis, T. A. (1983). Organizational determinants of job stress, 32,160-177.

Rafferty, A. E. \& Griffin, M. A. (2006). Refining individualized consideration: Distinguishing developmental leadership and supportive leadership. Journal of Occupational and Organizational Psychology, 79, 3761.

Reio, T. G. (1997). Effects of curiosity on socialization-related learning and job performance in adults. (Unpublished dissertation thesis). Virginia: Polytechnic Institute.

Retelsdorf, J., Butler, R., Streblow, L. \& Schiefele, U. (2009). Teachers' goal orientations for teaching: Associations with instructional practices, interest in teaching, and burnout. Learning and Instruction, 20, 1-17.

Rose, M. (2003). Good deal, bad deal? Job satisfaction in occupations. Work Employment Society, 17, 503.

Rowld, J. \& Schlotz, W. (2009). Transformational and transactional leadership and followers' chronic stress. Leadership Review, 9, 35-48.

Sass, D. A., Seal, A. K. \& Martin, N. K. (2011). Predicting teacher retention using stress and support variables. Journal of Educational Administration, 49(2), 200-215.

Schuler, R. S. (1977). The effects of role perceptions on employee satisfaction and performance moderated by employee ability. Organizational Behavior and Human Performance, 18, 98-107.

Shikieri, A. B. E. \& Musa, H. A. (2012). Factors Associated with Occupational Stress and Their Effects on Organizational Performance in a Sudanese University. Scientific Research, 3(1), 134-144.

Smith, E., Anderson, J. L. \& Lovrich, N. P. (1995). The multiple sources of workplace stress among land-grant university faculty. Research in Higher Education, 36, 261-282.

Stamper L. C. \& Johlke, C. M. (2003). The impact of perceived organizational support on the relationship between boundary spanner role stress and work outcomes. Journal of Management, 29, 569.

Szilagyi, A. D., Sims, H. P. \& Keller, R. T. (1976). Role dynamics, locus of control, and employee attitudes and behavior. Academy of Management Journal, 19, 259-276.

Wren, J. T. (1995). The Leader's Companion: Insights 21on Leadership through the ages, NewYork: Free Press.

Wallace, J. C, Edwards, B. D., Arnold, T. \& Frazier, M. L. (2009). Work stressors, role-based performance, and the moderating influence of organizational support. Journal of Applied Psychology, 94(1), 254-262.

Welford, A. T. (1973). Stress and performance. Ergonomics, 16(5), 567-580.

Westman, M. (2005). Crossover of stress and strain between spouses. In M. Pitt-Catsouphes, E.E. Kossek, and P. Raskin (Eds.), Sloan Work and Family Encyclopedia. Chestnut Hill, MA: Sloan Work and Family Research Network.

$\mathrm{Wu}, \mathrm{Y}$. (2011). Job stress and job performance among employees in the Taiwanese finance sector: The role of emotional intelligence. Social Behavior and Personality, 39(1), 21-32. 